\title{
Purification and characterization of an intracellular aminopeptidase from a wild strain of Lactobacillus plantarum isolated from traditional Serra da Estrela cheese
}

\author{
Angela C. Macedo $^{\mathrm{a}, \mathrm{b}}$, Tânia G. Tavares ${ }^{\mathrm{a}, \mathrm{c}}$, F. Xavier Malcata ${ }^{\mathrm{a}, *}$ \\ ${ }^{a}$ Escola Superior de Biotecnologia, Universidade Católica Portuguesa, Rua Dr. António Bernardino de Almeida, P-4200-072 Porto, Portugal \\ ${ }^{\mathrm{b}}$ Instituto Superior da Maia, Lugar de Vilarinho, S. Pedro de Avioso, P-4475 Castelo da Maia, Portugal \\ ${ }^{c}$ Departamento de Química, Faculdade de Ciências, Universidade do Porto, Rua do Campo Alegre, P-4169-007 Porto, Portugal
}

Keywords: Enzyme; Isolation; Activity; Lactic acid bacteria; Dairy food

\begin{abstract}
An intracellular hydrolase able to cleave L-lysine-p-nitroanilide was purified from Lactobacillus plantarum strain ESB5004 via two steps of precipitation with ammonium sulfate (at 30 and $50 \%(\mathrm{w} / \mathrm{v})$ ), followed by hydrophobic interaction and ion-exchange chromatographies. The aminopeptidase was purified up to 11 -fold, with a final yield of ca. $1 \%$. Its native molecular weight is ca. $70 \mathrm{kDa}$, and it is apparently composed of two subunits, the molecular weight of which is $34 \mathrm{kDa}$. The enzyme was assayed using a wide variety of $p$-nitroanilide ( $p$ NA) derivatives as substrates: it hydrolyzed preferentially $p$ NA adducts of hydrophobic and basic amino acid residues; no hydrolysis was in particular observed of Glu- $p$ NA, Gly- $p$ NA or Pro- $p$ NA. The enzyme activity was removed by the metal-chelating agent EDTA, thus suggesting that it is a metallo-enzyme; however, the EDTA-inhibited enzyme was reactivated in the presence of $\mathrm{Co}^{2+}$. Optimal aminopeptidase activity was obtained at $28^{\circ} \mathrm{C}(\mathrm{pH} 7.0)$ and $\mathrm{pH} 6.5\left(37^{\circ} \mathrm{C}\right)$. The enzyme was inhibited by $10 \mathrm{mM} \mathrm{CaCl}_{2}$ or $\mathrm{MgCl}_{2}$.
\end{abstract}

\section{Introduction}

The peptidases of lactic acid bacteria (LAB) used as starters in the dairy industry have been the focus of considerable attention in recent years, because of their role in the degradation of milk proteins during manufacture of such fermented milk products as cheese. Hydrolysis of milk proteins is seminal to help satisfy the amino acid requirements for $\mathrm{LAB}$ growth; it is also crucial for the development of typical organoleptic properties of dairy products, viz. taste and texture [1]. The multienzymatic system of LAB is composed of cell wall bound proteinases, responsible for the first step of casein hydrolysis, as well as several peptide- and amino acid-transport systems, and various intracellular peptidases (mainly aminopeptidases and dipeptidases) implicated in the release of single amino acids [2]; the proteolytic/peptidasic activities of many LAB have thus been extensively studied, and several

* Corresponding author.

E-mail address: xmalcata@esb.ucp.pt (F. X. Malcata). such enzymes were indeed isolated and duly characterized [1].

Most studies encompassing peptide profiles have initially used lactococci as model microorganisms owing to their importance as primary strains in cheese making. More recently, the interest has been somehow redirected towards the role of nonstarter LAB, mainly lactobacilli; the data available to date actually indicate that lactobacilli possess even wider peptidase activity profiles than lactococci do [3].

Serra da Estrela cheese is economically and organoleptically the most important variety of traditional cheese manufactured in Portugal. The microflora in this raw ewe's milk cheese is qualitatively and quantitatively diverse, with clear dominance of LAB. Studies pertaining to the ecology patterns of LAB during ripening of that cheese clearly demonstrated the existence of competition and gradual replacement of Lactococcus spp. by Lactobacillus spp.; Lactobacillus paracasei and Lactobacillus plantarum are those species more consistently present in the final stages of ripening [4]. Despite their abundance, relatively little is known about their actual role in the pathways of flavor development. 
This paper describes the purification and characterization of a novel intracellular aminopeptidase from $L$. plantarum strain ESB5004, previously isolated from the adventitious microflora of Serra da Estrela cheese, in attempts to better understand its specific contribution upon maturation. The scientific relevance arises from the fact that such enzyme, produced by a strain of the wild microflora, had not to date been characterized; the practical relevance lays on its potential use as part of a tailor-made enzyme mixture, aimed specifically at contributing to the unique organoleptic profile of that traditional cheese.

\section{Materials and methods}

\subsection{Bacterial strain, growth conditions and harvesting}

The strain used, L. plantarum ESB5004, had been isolated from Serra da Estrela cheese as described previously by Macedo et al. [4], and identified using sodium dodecyl sulfate (SDS)-PAGE protein profiling analysis (BCCM ${ }^{\mathrm{TM}} / \mathrm{LMG}$ ID4916, Gent, Belgium). The harvested cells were stored at $-80{ }^{\circ} \mathrm{C}$ as stock solutions in $30 \%(\mathrm{v} / \mathrm{v})$ aqueous glycerol. Inoculation at $1 \%(\mathrm{v} / \mathrm{v})$ of the stock culture of L. plantarum ESB5004 was performed in $60 \mathrm{ml}$ of MRS broth (Merck, Darmstad, Germany). After incubation at $37^{\circ} \mathrm{C}$ for ca. $16 \mathrm{~h}$, these microorganisms were similarly subcultured in the same medium $(1200 \mathrm{ml})$. A final inoculation at $5 \%(\mathrm{v} / \mathrm{v})$ on 241 of fresh medium was subsequently made; the medium was then incubated overnight at $37^{\circ} \mathrm{C}$ for ca. $14 \mathrm{~h}$. Harvest, at the late exponential phase, was by centrifugation at $7000 \times g$ and $4{ }^{\circ} \mathrm{C}$ for $10 \mathrm{~min}$ [5].

\subsection{Preparation of cell-free extract}

Harvested cells were washed twice in $50 \mathrm{mM}$ sodium phosphate buffer ( $\mathrm{pH} 7.0$ ), and collected by centrifugation at $13,000 \times g$ and $4{ }^{\circ} \mathrm{C}$ for $50 \mathrm{~min}$. The washed pellet was incubated in a water bath, under slight agitation, for $2 \mathrm{~h}$ at $30^{\circ} \mathrm{C}$ in phosphate buffer containing $0.4 \mathrm{mg} / \mathrm{ml}$ lysozyme (Sigma, St. Louis MO, USA) and $42 \mathrm{U} / \mathrm{ml}$ mutanolysine (Sigma). The spheroblasts were then disrupted, after addition of glass beads (150-212 $\mu \mathrm{m}$, from Sigma), in an ice bath by a domestic blender (Troia, Porto, Portugal) for four periods of $4 \mathrm{~min}$ each. The mixture was centrifuged at $15,000 \times g$ and $4{ }^{\circ} \mathrm{C}$ for $50 \mathrm{~min}$. Nucleic acids in the supernatant were hydrolyzed by addition of RNAse at $0.0275 \mathrm{mg} / \mathrm{ml}_{\text {extract }}$ (Sigma) and DNAse at $0.0005 \mathrm{mg} / \mathrm{ml}_{\text {extract }}$ (Sigma), in the presence of magnesium chloride at $0.017 \mathrm{mg} / \mathrm{ml}_{\text {extract }}$, using a water bath with slight agitation at $30^{\circ} \mathrm{C}$ for $2.5 \mathrm{~h}$; they were then precipitated in the presence of $60 \mathrm{mM} \mathrm{MnSO}_{4}$. The suspension was left at $4{ }^{\circ} \mathrm{C}$ during $1 \mathrm{~h}$; the cell debris were then removed by centrifugation at $33,500 \times g$ and $4{ }^{\circ} \mathrm{C}$ for $30 \mathrm{~min}$. The supernatant obtained, designated hereafter as cell-free extract (CFE), was kept frozen at $-30^{\circ} \mathrm{C}$ in Eppendorf vials until the enzyme assays were in order.

\subsection{Determination of protein concentration}

Protein amounts in the CFE and in the purified enzyme fractions were determined by the method of Bradford [6]; bovine serum albumin (Sigma) was used as standard for calibration.

\subsection{Determination of enzyme activity}

The aminopeptidase activity was assayed at $37^{\circ} \mathrm{C}$ and $\mathrm{pH}$ 7.0 using L-lysine- $p$-nitroanilide (Lys- $p$ NA, from Sigma) as substrate, according to the method described by Macedo et al. [5]. The specific activity was expressed as millimole of substrate hydrolyzed per hour and per milligram of protein.

\subsection{Purification of enzyme}

All purification steps were carried out at room temperature (ca. $20^{\circ} \mathrm{C}$ ), and the aminopeptidase activity of every fraction collected was evaluated as described previously. The purified enzyme fraction was obtained after the three-step procedure described next.

\subsubsection{Step 1: ammonium sulfate fractionation}

The CFE was fractionated with ultrapure $\left(\mathrm{NH}_{4}\right)_{2} \mathrm{SO}_{4}$ (Sigma) in two steps (30 and 50\% (w/v)) via incubation at $4{ }^{\circ} \mathrm{C}$ for $90 \mathrm{~min}$. Fractions were collected by centrifugation at $38,000 \times g$ and $4{ }^{\circ} \mathrm{C}$ for $30 \mathrm{~min}$. The hydrolase activity on Lys- $p$ NA was detected in the precipitate formed between 30 and $50 \%(\mathrm{w} / \mathrm{v})$, after it had been redissolved in phosphate buffer; this fraction was designated as ammonium sulfate fraction, ASF.

\subsubsection{Step 2: hydrophobic interaction chromatography}

A fast protein liquid chromatography (FPLC) system (Pharmacia Biotech, Uppsala, Sweden) was used with a HiLoad 16/10 Phenyl Sepharose High Performance column (Pharmacia), which was equilibrated with $100 \mathrm{mM}$ sodium phosphate buffer ( $\mathrm{pH} 7.0)$ containing $1.7 \mathrm{M}\left(\mathrm{NH}_{4}\right)_{2} \mathrm{SO}_{4}$. The proteins were eluted at a flow rate of $180 \mathrm{ml} / \mathrm{h}$ using a linear gradient decreasing from 1.7 to $0.0 \mathrm{M}\left(\mathrm{NH}_{4}\right)_{2} \mathrm{SO}_{4}$ in $2 \mathrm{~h}$. Fractions $(5 \mathrm{ml})$ were collected sequentially, and those possessing the highest enzyme activity were pooled together and desalted by passing through a HiPrep 26/10 Desalting column (Sephadex G-25 Fine, from Pharmacia) equilibrated with $20 \mathrm{mM}$ Bis-Tris (pH 7.0). The desalted fraction, designated as hydrophobic interaction chromatography fraction, HICF, was concentrated by centrifugation at $3000 \times g$ and $4{ }^{\circ} \mathrm{C}$ for $115 \mathrm{~min}$ using a Centriplus YM10 filter (from Millipore, Bedford MA, USA).

\subsubsection{Step 3: anion-exchange chromatography}

The concentrated HICF fraction was applied to a HiTrap Q Sepharose High Performance column (Pharmacia), 
equilibrated with $20 \mathrm{mM}$ Bis-Tris ( $\mathrm{pH} 7.0$ ). The bound protein was eluted at a flow rate of $300 \mathrm{ml} / \mathrm{h}$, under a linear $\mathrm{NaCl}$ gradient increasing from 0.0 to $0.5 \mathrm{M}$ in $0.42 \mathrm{~h}$, in the same buffer. The fractions possessing aminopeptidase activity were pooled together, desalted through a HiPrep 26/10 Desalting column equilibrated with $100 \mathrm{mM}$ sodium phosphate ( $\mathrm{pH} 7.0$ ), and duly lyophilized. The purified enzyme was then redissolved in $6 \mathrm{ml}$ of phosphate buffer; this fraction was designated as anion-exchange chromatography fraction, AECF.

The overall purification factor was calculated for each step by dividing the specific activity after that step by the initial specific activity. The overall activity yield was calculated by dividing the activity of the material recovered at that purification step by the activity of the CFE.

\subsection{Determination of purity}

To monitor the progress of purification of the enzyme, polyacrylamide gel electrophoresis (PAGE) was performed using a PhastSystem (Pharmacia). Electrophoresis was carried out with Gradient 10-15 gels (Pharmacia) and native buffer strips (Pharmacia). Coomassie Brilliant Blue R-250 (Merck) was used to visualize the protein bands.

\subsection{Determination of molecular weight of purified enzyme and subunits}

The molecular weight of the purified enzyme was determined by gel filtration on a $2.6 \mathrm{~cm} \times 60 \mathrm{~cm}$ HiPrep Sephacryl S-100 High Resolution column (Pharmacia), previously equilibrated with $100 \mathrm{mM}$ sodium phosphate ( $\mathrm{pH} 7.0$ ) containing $0.15 \mathrm{M} \mathrm{NaCl}$, at $78 \mathrm{ml} / \mathrm{h}$. The column was calibrated using ribonuclease A $(11,900 \mathrm{Da})$, chymotrypsinogen A $(19,500 \mathrm{Da})$, ovalbumin $(48,200 \mathrm{Da})$ and albumin $(73,500 \mathrm{Da})$ as standards (Sigma).

To determine the molecular weight of the enzyme subunits, SDS-PAGE was performed as described by Laemmli [7], using the PhastSystem (Pharmacia) equipment and protocols. Electrophoresis was carried out with Homogeneous 12.5 gels (Pharmacia) and SDS buffer strips (Pharmacia). Coomassie Brilliant Blue R-250 was used to visualize the protein bands. The molecular weights of the enzyme subunits were estimated using phosphorylase $(97,000 \mathrm{Da})$, albumin $(66,000 \mathrm{Da})$, ovalbumin $(45,000 \mathrm{Da})$, carbonic anhydrase $(30,000 \mathrm{Da})$, trypsin inhibitor $(20,100 \mathrm{Da})$ and $\alpha$-lactalbumin $(14,400 \mathrm{Da})$ as standards (Sigma).

\subsection{Determination of substrate specificity}

The affinity of the purified aminopeptidase for various amino acid residues was determined as described previously [5], employing Ala- $p \mathrm{NA}$, Arg- $p \mathrm{NA}$, Glu- $p \mathrm{NA}$, Gly- $p \mathrm{NA}$, Leu- $p$ NA, Lys- $p$ NA, Met- $p$ NA, Pro- $p$ NA and Val- $p$ NA (Sigma) as model substrates. The activity on Lys- $p$ NA was taken as reference for the aminopeptidase activity.

\subsection{Effect of EDTA on enzyme activity}

The enzyme was preincubated with EDTA (Sigma) at $37^{\circ} \mathrm{C}$ for $30 \mathrm{~min}$, at a final concentration of $1 \mathrm{mM}$ in $50 \mathrm{mM}$ Tris- $\mathrm{HCl}$ (pH 7.0). The activity was then assayed at $37^{\circ} \mathrm{C}$ using Lys- $p$ NA as substrate; the activity was expressed using the activity of Lys- $p$ NA in the absence of EDTA as a basis. After inactivation with $1 \mathrm{mM}$ EDTA, the purified aminopeptidase was incubated with $1 \mathrm{mM} \mathrm{CoCl}_{2}$ (Merck) at $37^{\circ} \mathrm{C}$ for $30 \mathrm{~min}$ before the (restored) activity was again measured as described previously. The activity of the purified enzyme on Lys- $p \mathrm{NA}$, in the absence of EDTA and $\mathrm{Co}^{2+}$, was taken as reference for the aminopeptidase activity.

\subsection{Effect of cations on enzyme activity}

The enzyme was preincubated with various chloride salts, viz. $\mathrm{NaCl}, \mathrm{CaCl}_{2}, \mathrm{MgCl}_{2}, \mathrm{MnCl}_{2}$ and $\mathrm{ZnCl}_{2}$ (Merck) at $37^{\circ} \mathrm{C}$ for $20 \mathrm{~min}$, at a final concentration of 1 and $10 \mathrm{mM}$, in $50 \mathrm{mM}$ Tris- $\mathrm{HCl}(\mathrm{pH} 7.0)$. The activity was then assayed at $37^{\circ} \mathrm{C}$ using Lys- $p$ NA as substrate; the activity was expressed using the activity on Lys- $p$ NA in the absence of cations as reference.

\subsection{Effect of temperature on enzyme activity}

The effect of temperature on the aminopeptidase activity was determined in the range $20-55^{\circ} \mathrm{C}$ using Lys- $p \mathrm{NA}$ as substrate, after incubation of the enzyme for $20 \mathrm{~min}$ at the desired temperature, in $100 \mathrm{mM}$ sodium phosphate buffer (pH 7.0). The activity was normalized by the highest activity recorded.

\subsection{Effect of $p H$ on enzyme activity}

The effect of $\mathrm{pH}$ on the aminopeptidase activity was determined at $37^{\circ} \mathrm{C}$ in the range $4-10$, using as substrate Lys- $p$ NA with the following $100 \mathrm{mM}$ buffers: sodium acetate/acetic acid ( $\mathrm{pH} 4.0$ and 5.0), sodium phosphate $(\mathrm{pH}$ 6.0, 7.0 and 8.0) and glycine/ $\mathrm{NaOH}(\mathrm{pH} 9.0$ and 10.0). The enzyme was preincubated at the desired $\mathrm{pH}$ at $37^{\circ} \mathrm{C}$ for $5 \mathrm{~min}$. The activity was normalized by the highest activity measured.

\section{Results}

The yields and degrees of purification of the aminopeptidase present in the CFE of $L$. plantarum strain ESB5004, active on Lys- $p$ NA, are summarized in Table 1; chromatographic elution profiles are shown in Fig. 1. Ammonium sulfate precipitation at $50 \%(\mathrm{w} / \mathrm{v})$ yielded $60 \%$ of the starting aminopeptidase activity, and caused a 1.3 -fold increase in the specific activity. Hydrophobic interaction chromatography on HiLoad 16/10 Phenyl Sepharose led to separation of the enzyme responsible for the Lys- $p$ NA hydrolyzing 

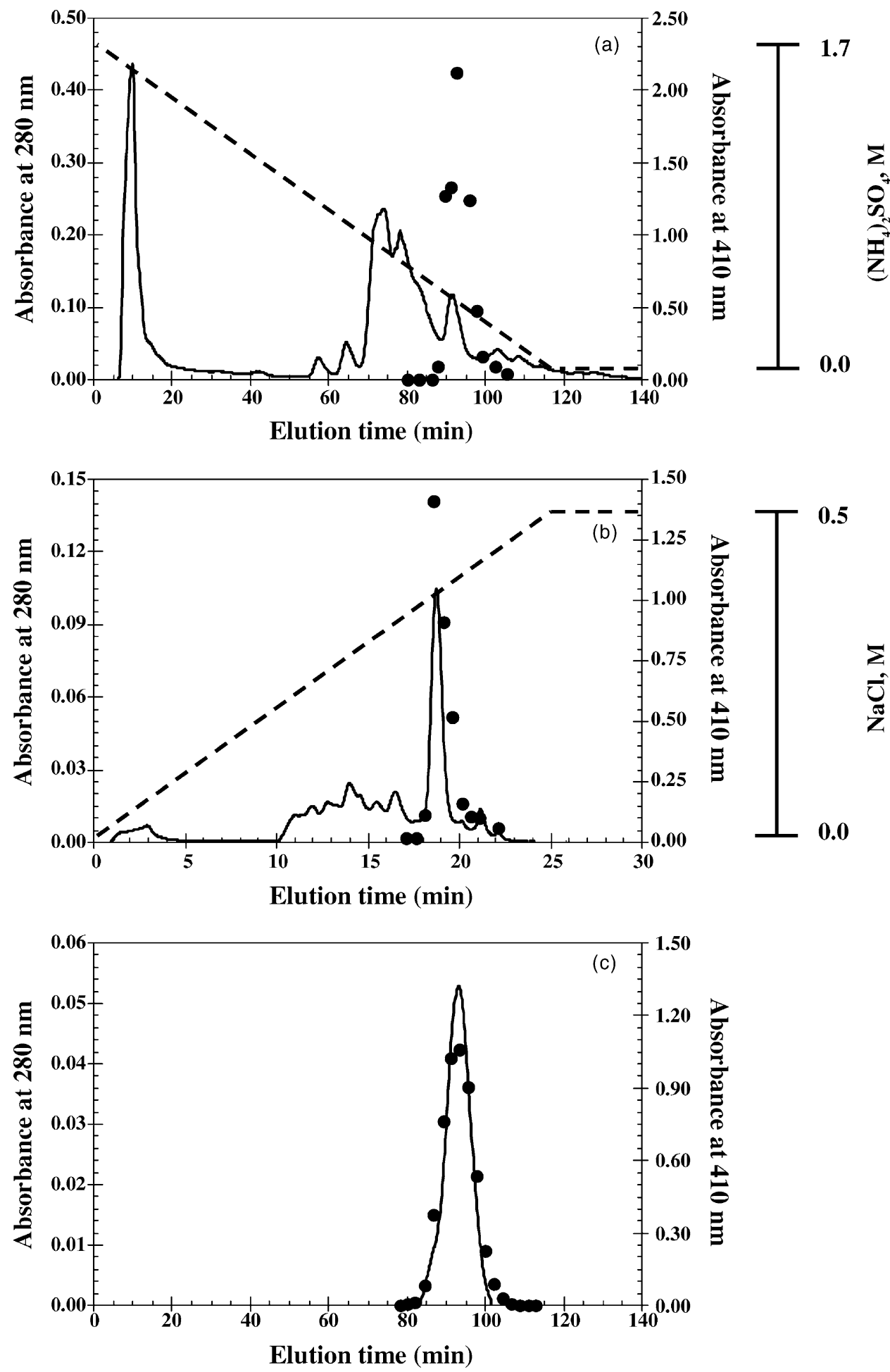

Fig. 1. Elution protein profile (protein absorbance at $280 \mathrm{~nm},-$ ), aminopeptidase activity profiles ( $p$ NA absorbance at $410 \mathrm{~nm}$, $)$ and eluent gradient profile $\left(\mathrm{NH}_{4}\right)_{2} \mathrm{SO}_{4}$ or $\mathrm{NaCl}$, from the cell-free extract of L. plantarum ESB5004 (---) by chromatography on (a) HiLoad 16/10 Phenyl Sepharose, (b) HiTrap Q Sepharose, and (c) HiPrep Sephacryl S-100.

activity, which was eluted at $0.43 \mathrm{M}\left(\mathrm{NH}_{4}\right)_{2} \mathrm{SO}_{4}$ (Fig. 1a). This step (after active fractions had been pooled together and duly desalted) allowed recovery of $28 \%$ of the total activity, and a three-fold increase in the specific activity.
Anion-exchange chromatography on HiTrap Q Sepharose of the active fraction obtained in the previous step resulted in a fraction active on Lys- $p$ NA that was eluted as a peak at $0.44 \mathrm{M} \mathrm{NaCl}$ (Fig. 1b). After desalting and concentrating 
Table 1

Effect of individual purification steps on the activity of aminopeptidase from L. plantarum ESB5004

\begin{tabular}{lclrr}
\hline Purification step & $\begin{array}{l}\text { Total protein } \\
(\mathrm{mg})\end{array}$ & $\begin{array}{l}\text { Total activity } \\
(\mu \mathrm{mol} / \mathrm{h})\end{array}$ & \multicolumn{2}{l}{$\begin{array}{l}\text { Specific activity } \\
(\mu \mathrm{mol} / \mathrm{h} \mathrm{mg})\end{array}$} \\
\hline $\mathrm{CFE}^{\mathrm{a}}$ & 822.3 & 612.7 & 0.7 & 100 \\
$\mathrm{ASF}^{\mathrm{b}}$ & 381.4 & 367.2 & 1.0 & 60 \\
$\mathrm{HICF}^{\mathrm{c}}$ & 76.1 & 170.8 & 2.2 & 1.0 \\
$\mathrm{AECF}^{\mathrm{d}}$ & 0.4 & 3.2 & 7.9 & 3.0 \\
\hline
\end{tabular}

${ }^{a}$ CFE: cell- and nucleic acid-free extract.

${ }^{b}$ ASF: ammonium sulfate fraction, precipitated between 30 and $50 \%(\mathrm{w} / \mathrm{v})$.

${ }^{c}$ HICF: hydrophobic interaction chromatography fraction, using HiLoad 16/10 Phenyl Sepharose.

d AECF: anion-exchange chromatography fraction, using HiTrap Q Sepharose.

the pooled active fractions obtained in this step, the AECF fraction exhibited a 10.6-fold increase in specific activity relative to that of the CFE, although only $1 \%$ recovery of the total activity was possible.

Native-PAGE electrophoretograms of preparations obtained after the various purification steps are shown in Fig. 2. A single band was detected after the purification with the HiTrap Q column, so the purification process was considered complete. The molecular weight of the purified enzyme was estimated as $70 \mathrm{kDa}$ by gel filtration chromatography on Sephacryl S-100; the chromatographic

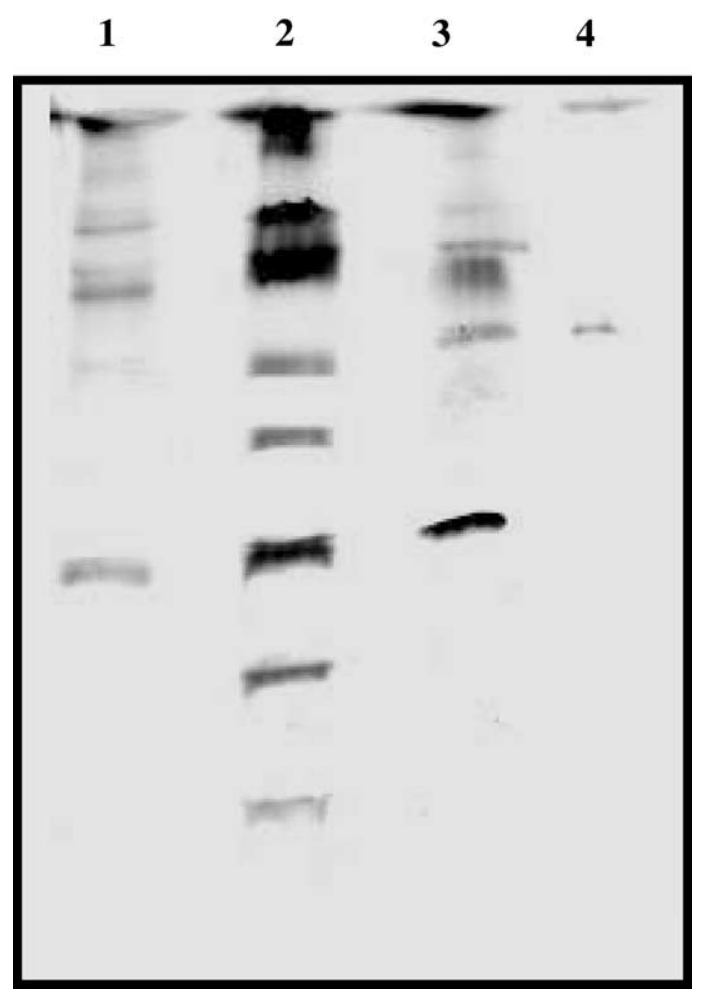

Fig. 2. Native-PAGE electrophoretograms of the cell-free extract and of the chromatographic fractions containing aminopeptidase activity; cell-free extract (lane 1), fraction obtained after fractionation with $\left(\mathrm{NH}_{4}\right)_{2} \mathrm{SO}_{4}$ (lane 2), fraction obtained after resolution by HiLoad 16/10 Phenyl Sepharose (lane 3), and fraction obtained after resolution by HiTrap Q Sepharose (lane 4). elution profile showed a single peak, with a retention time of $93.4 \mathrm{~min}$ (Fig. 1c). SDS-PAGE electrophoretograms of the preparations obtained after the sequential purification steps indicated that the enzyme is composed of subunits with molecular weight $34 \mathrm{kDa}$ (Fig. 3).

The hydrolytic action of the purified enzyme towards different substrates is shown in Table 2. Amongst the $p$-nitroanilide derivatives assayed, the aminopeptidase was most active on Leu- $p$ NA, followed by Arg- $p$ NA, Lys- $p$ NA, Val- $p$ NA, Ala- $p$ NA and Met- $p$ NA. No activity whatsoever was detected against Glu- $p$ NA, Gly- $p$ NA and Pro- $p$ NA, at least under the assay conditions tested.

No aminopeptidase activity was observed after incubation of the purified enzyme with $1 \mathrm{mM}$ EDTA, a metal-chelating agent; however, the enzyme activity was restored, and even enhanced (up to 1.3-fold) by addition of $1 \mathrm{mM} \mathrm{CoCl} 2$.

Table 2

Substrate specificity of purified aminopeptidase of L. plantarum ESB5004

\begin{tabular}{lc}
\hline Amino acid- $p \mathrm{NA}^{\mathrm{a}}$ & Relative activity $(\%)$ \\
\hline Lys & 100 \\
Ala & 23 \\
Arg & 177 \\
Glu & 0 \\
Gly & 0 \\
Leu & 185 \\
Met & 23 \\
Pro & 0 \\
Val & 92 \\
\hline
\end{tabular}

${ }^{\mathrm{a}} p \mathrm{NA}$ : $p$-nitroanilide.

Table 3

Effect of different concentrations of cations (at $37^{\circ} \mathrm{C}$ and $\mathrm{pH}$ 7.0) on the activity of aminopeptidase of L. plantarum ESB5004

\begin{tabular}{llc}
\hline Salt & \multicolumn{2}{l}{ Relative activity $(\%)$} \\
\cline { 2 - 3 } & $1 \mathrm{mM}$ & $10 \mathrm{mM}$ \\
\hline Control & 100 & 100 \\
$\mathrm{NaCl}$ & 120 & 124 \\
$\mathrm{CaCl}$ & 136 & 1 \\
$\mathrm{MgCl}_{2}$ & 119 & 2 \\
$\mathrm{MnCl}_{2}$ & 136 & 131 \\
$\mathrm{ZnCl}_{2}$ & 129 & 145 \\
\hline
\end{tabular}




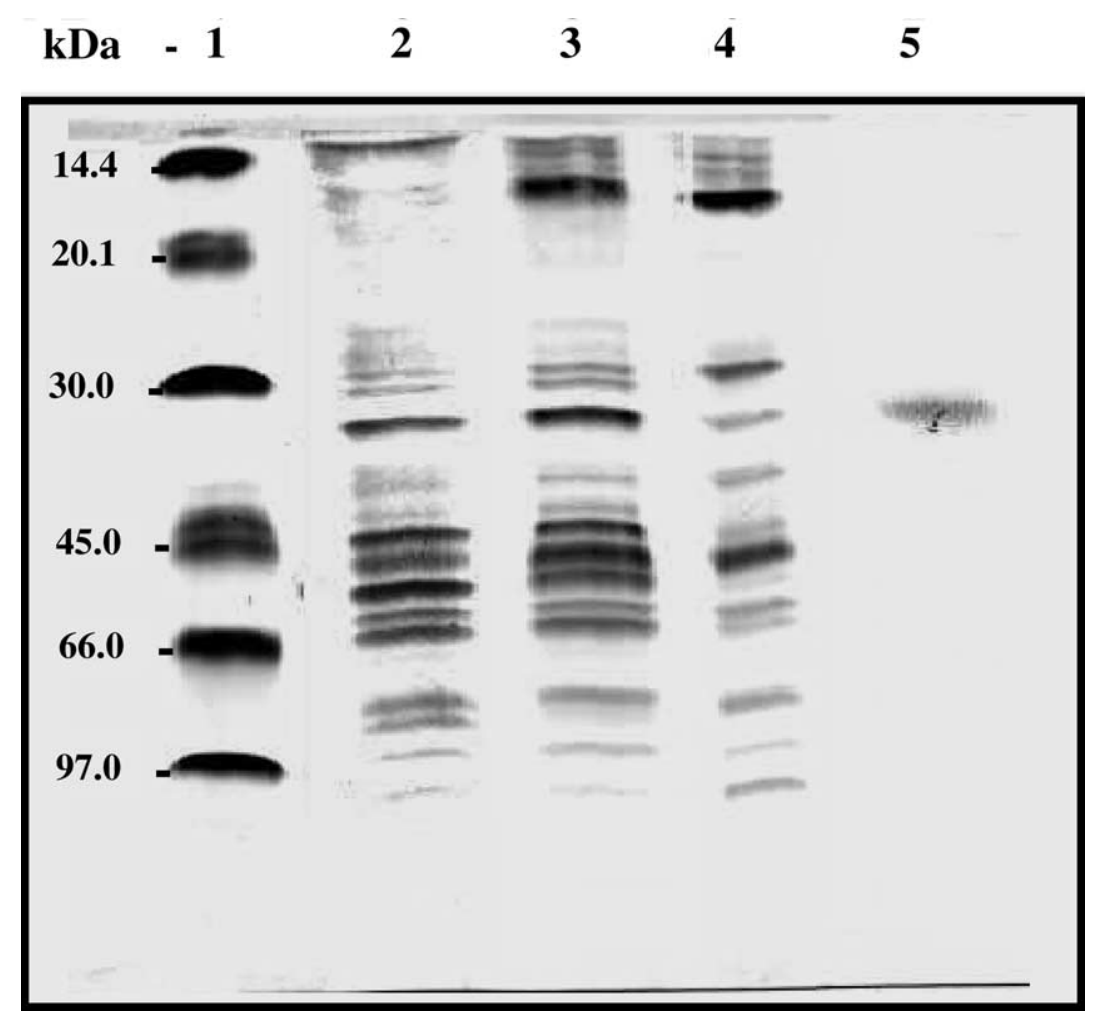

Fig. 3. SDS-PAGE electrophoretograms of the cell-free extract and of the chromatographic fractions containing aminopeptidase activity; molecular weight standards $\left(\mathrm{kDa}\right.$; lane 1), cell-free extract (lane 2), fraction obtained after fractionation with $\left(\mathrm{NH}_{4}\right)_{2} \mathrm{SO}_{4}$ (lane 3), fraction obtained after resolution by HiLoad 16/10 Phenyl Sepharose (lane 4), and fraction obtained after resolution by HiTrap Q Sepharose (lane 5).

The effect of selected cations on the enzyme activity is shown in Table 3. The presence of $\mathrm{Na}^{+}, \mathrm{Mn}^{2+}$ and $\mathrm{Zn}^{2+}$, at 1 and $10 \mathrm{mM}$, and of $\mathrm{Ca}^{2+}$ and $\mathrm{Mg}^{2+}$, at $1 \mathrm{mM}$, caused an increase of the enzyme activity on Lys- $p$ NA. However, the presence of the divalent cations $\mathrm{Ca}^{2+}$ and $\mathrm{Mg}^{2+}$, at $10 \mathrm{mM}$, removed almost all aminopeptidase activity.

The effect of temperature, from 20 to $55^{\circ} \mathrm{C}$, on the activity of the purified aminopeptidase at pH 7.0 is shown in Fig. 4. The optimum temperature for the aminopeptidase activity

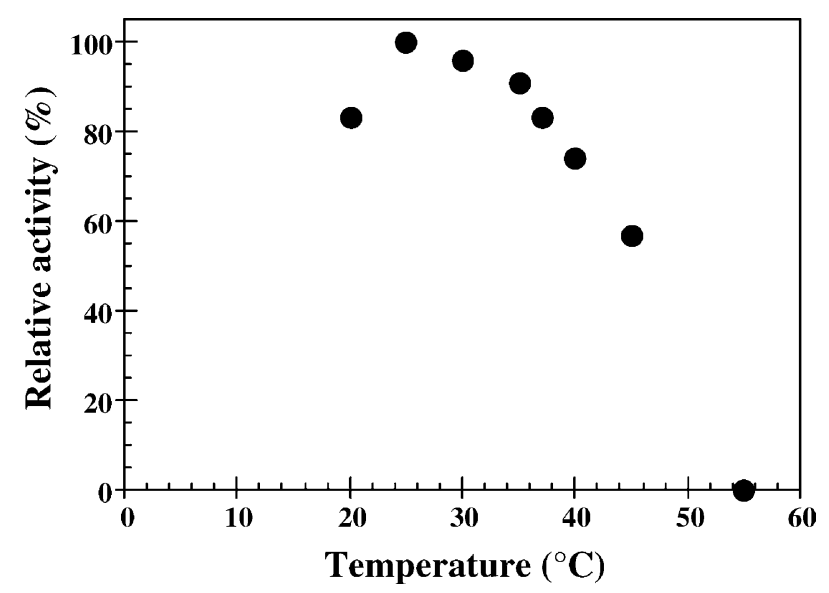

Fig. 4. Effect of temperature on the activity of purified aminopeptidase on Lys- $p \mathrm{NA}$, in $100 \mathrm{mM}$ phosphate buffer $(\mathrm{pH} 7.0)$. acting on Lys- $p \mathrm{NA}$ is ca. $28^{\circ} \mathrm{C} ; 80 \%$ of the maximum activity was recorded at 20 and $37^{\circ} \mathrm{C}$, and no aminopeptidase activity was found at $55^{\circ} \mathrm{C}$. Additionally, the enzyme activity on Lys- $p$ NA was at least $60 \%$ of its maximum activity in the $\mathrm{pH}$ range $5-8$; the optimum activity was observed at pH 6.5, as apparent in Fig. 5.

Although an aminopeptidase is strictly speaking an enzyme that brings about the hydrolysis of the peptide bond between two amino acids from the $\mathrm{N}$-terminus, and the

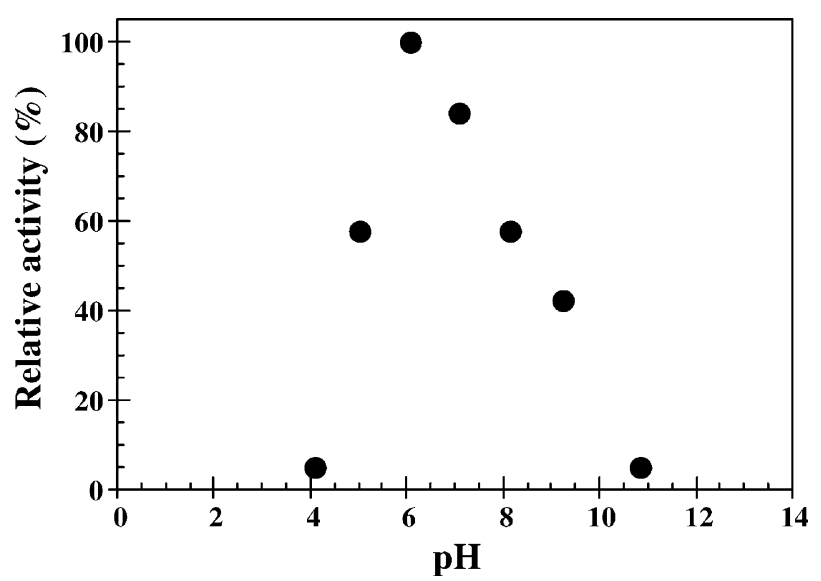

Fig. 5. Effect of $\mathrm{pH}$ on the activity of purified aminopeptidase on Lys- $p \mathrm{NA}$, at $37^{\circ} \mathrm{C}$. 
experimental work only assayed for the activity of the enzyme in stake on aryl (i.e. $p$-nitroanilide moieties) rather than peptide bonds, Macedo et al. [5] have previously show that this type of enzyme was able to cleave the dipeptide Leu-Ser among others; for this reason, the enzyme was termed aminopeptidase throughout the text.

\section{Discussion}

The experimental data generated have indicated that fractionation with ammonium sulfate was not particularly efficient, considering that only a 1.3 -fold increase in the specific activity could be attained; however, this step was important toward volume reduction, protein concentration and viscosity decrease of the CFE, as well as in sample preparation for the following step (in which addition of 1.7 $\mathrm{M}$ ammonium sulfate was required before injection into the Phenyl Sepharose column). The latest step, i.e. chromatography on HiTrap Q, was the one that led to the highest single increase of specific activity.

The purified enzyme, in its native state, consists of two subunits of $34 \mathrm{kDa}$, considering that the molecular weight of the enzyme, determined by gel filtration, has been estimated as ca. $70 \mathrm{kDa}$, and that the molecular weight of the protein domains, determined by SDS-PAGE under reducing conditions, was estimated as ca. $34 \mathrm{kDa}$. The aminopeptidases isolated so far from $\mathrm{LAB}$ are characterized either by a monomeric structure (with a molecular weight of 75-98 kDa), viz. PepN-type [1], by a tetrameric or hexameric structure (with molecular weight of $200-300 \mathrm{kDa}$ ), viz. PepC-type [1], or by a trimeric, hexameric or octameric structure (with molecular weight of $29-360 \mathrm{kDa}$ ), viz. PepA-type [1].

The aminopeptidase isolated from the CFE of $L$. plantarum strain ESB5004 showed a broad substrate specificity, and exhibited preference for $p$ NA derivatives of hydrophobic (Leu- $p$ NA and Val- $p$ NA) and positively charged (Lys- $p$ NA and Arg- $p$ NA) amino acid residues, although hydrophobic amino acid residues (such as Leu- $p$ NA) are preferentially attacked rather than basic ones (such as Lys- $p$ NA). Additionally, this purified enzyme exhibits significant activity towards Met- $p$ NA and it is unable to hydrolyze Glu- $p$ NA and Gly- $p$ NA. However, the realization that its specificity towards basic amino acid residues is lower than that for hydrophobic ones and that the enzyme is supposed to exhibit significant activity towards Glu- $p$ NA and Gly- $p$ NA, disagrees with data reported elsewhere [1] for PepN-type and for PepC-type, respectively. The characterization of the purified enzyme according to hydrolysis of chromogenic substrates is technologically convenient in view of the fact that basic amino acid residues at the $\mathrm{N}$-terminus do apparently enhance peptide bitterness to a significant extent [8]; hence, release of positively charged amino acid residues by the aminopeptidase from L. plantarum ESB5004 suggests that it may have an impact on cheese debittering. How- ever, this information does not fully elucidate the putative specific role of this enzyme in hydrolysis of exogeneous peptides; therefore, the actual impact of said aminopeptidase remains to be demonstrated in cheese making trials.

The inhibitor of metallo-enzymes, EDTA, inactivates the purified enzyme at a concentration as low as $1 \mathrm{mM}$; this piece of evidence suggests that this aminopeptidase is a metallo-dependent enzyme, and as such it behaves more likely as a PepN than a PepC; this is so because PepN-type aminopeptidases from various $\mathrm{LAB}$ strains are strongly inhibited by $0.1-1 \mathrm{mM}$ EDTA [9-11], whereas PepC-type aminopeptidases are not affected at all [12], or are even activated [13]. Additionally, it was observed that the metal cation $\mathrm{Co}^{2+}$, at $1 \mathrm{mM}$, was able to restore the activity of the EDTA-inhibited enzyme, and was even able to stimulate that activity.

Very low concentrations $(1 \mathrm{mM})$ of the cations $\mathrm{Na}^{+}$, $\mathrm{Mn}^{2+}, \mathrm{Zn}^{2+}, \mathrm{Ca}^{2+}$ and $\mathrm{Mg}^{2+}$ promoted the activity of the enzyme, with no trivially explained dependency of the activity on the type of ion. At higher concentrations $(10 \mathrm{mM})$, $\mathrm{Zn}^{2+}$ was the most effective, whereas $\mathrm{Ca}^{2+}$ and $\mathrm{Mg}^{2+}$ contributed to unstability of the enzyme and lower efficiency in release of free amino acids from their $p$ NA derivatives.

The purified enzyme showed optimal activity at ca. $28^{\circ} \mathrm{C}$ $(\mathrm{pH} 7.0)$ and at $\mathrm{pH} 6.5\left(37^{\circ} \mathrm{C}\right)$. Its optimum temperature is lower than those reported for aminopeptidases from strains of Lactobacillus spp., viz $30^{\circ} \mathrm{C}[14,15], 37^{\circ} \mathrm{C}$ [9], $40^{\circ} \mathrm{C}$ $[16], 45^{\circ} \mathrm{C}[8,10,17,18], 47.5^{\circ} \mathrm{C}[19]$ and $55^{\circ} \mathrm{C}[15]$; however, the optimum $\mathrm{pH}$ is essentially similar to the optimum values reported by those authors, which range from 6.0 to 7.5 .

\section{Conclusions}

This work demonstrated the existence in L. plantarum strain ESB5004 of a dimeric, $\mathrm{Co}^{2+}$-dependent metallo-aminopeptidase, with a total molecular weight of ca. $70 \mathrm{kDa}$. That aminopeptidase is distinct from general aminopeptidases (PepC and PepN) and glutamyl aminopeptidases (PepA) from Lactobacillus spp. that were reported to date in terms of molecular weight, substrate selectivity and metal cation dependency. Potential inclusion is an enzymatic mixture designed for Serra da Estrela cheese making (with debittering capacity) is now to be tested on pilot scale level.

\section{Acknowledgments}

To the FCT-Program PRAXIS XXI (Portugal), for the fellowship granted to Angela C. Macedo (BPD/20158/99), and to the FCT-Program POCTI (Portugal), for funding through project MICROCHEESE (POCTI/1999/BIO/36197) and ENTEROCOCCUS (POCTI/AGR/36165/99). 


\section{References}

[1] Christensen JE, Dudley EG, Pederson JA, Steele JL. Peptidases and amino acid catabolism in lactic acid bacteria. Ant Leeuwen 1999;76:217-46.

[2] Kunji ERS, Mierau I, Hagting A, Poolman B, Konings WN. The proteolytic system of lactic acid bacteria. Ant Leeuwen 1996;70:187-221.

[3] Ezzat N, El Soda M, Desmazeaud MJ, Ismail A. Peptide hydrolases from thermobacterium group of lactobacilli. III. Characterization of intracellular peptidases. Lait 1986;66:445-8.

[4] Macedo AC, Malcata FX, Hogg TA. Microbiological profile in Serra ewes' cheese during ripening. J Appl Bacteriol 1995;79:1-11.

[5] Macedo AC, Vieira M, Poças R, Malcata FX. Peptide hydrolase system of lactic acid bacteria isolated from Serra da Estrela cheese. Int Dairy J 2000;10:769-74.

[6] Bradford MM. A rapid and sensitive method for quantitation of microgram quantities of protein utilizing the principle of dye-binding. Anal Biochem 1976;72:248-54.

[7] Laemmli UK. Cleavage of structural proteins during the assembly of the head of bacteriophage T4. Nature 1970;227:196-204.

[8] Palencia PF, Felipe FL, Requena T, Peláez C. The aminopeptidase C (PepC) from Lactobacillus helveticus CNRZ32. A comparative study of PepC from lactic acid bacteria. Eur Food Res Technol 2000;212:89-94.

[9] Arora G, Lee BH. Purification and characterization of aminopeptidase from Lactobacillus casei ssp. casei LLG. J Dairy Sci 1992;75:70010.

[10] Khalid NM, Marth EH. Partial purification and characterization of an aminopeptidase from Lactobacillus helveticus CNRZ 32. Syst Appl Microbiol 1990;13:311-9.
[11] Miyakawa H, Kobayashi S, Shimamura S, Tomita M. Purification and characterization of an aminopopeptidase from Lactobacillus helveticus LHE-511. J Dairy Sci 1992;75:27-35.

[12] Neviani I, Boquien CY, Monnet V, Thanh LP, Gripon JC. Purification and characterization of an aminopeptidase from Lactococcus lactis subsp. cremoris AM2. Appl Environ Microbiol 1989;55:230814.

[13] Wohlrab Y, Bockelmann W. Purification and characterization of a second aminopeptidase (PepC-like) from Lactobacillus delbrueckii subsp. bulgaricus B14. Int Dairy J 1993;3:685-701.

[14] Gobbetti M, Smacchi E, Corsetti AA. The proteolytic system of Lactobacillus sanfrancisco CB1: purification and characterization of a proteinase, a dipeptidase, and an aminopeptidase. Appl Environ Microbiol 1996;62:3220-6.

[15] Palencia PF, Peláez C, Martín-Hernández MC. Characterization of the aminopeptidase system from Lactobacillus casei subsp. casei IFPL 731. J Agric Food Chem 1997;45:3778-81.

[16] Tsakalidou E, Dalezios I, Georgalaki M, Kalantzopoulos G. A comparative study: aminopeptidase activities from Lactobacillus delbrueckii ssp. bulgaricus and Streptococcus thermophilus. J Dairy Sci 1993;76:2145-51.

[17] Wohlrab Y, Bockelmann W. Purification and characterization of a new aminopeptidase from Lactobacillus delbrueckii subsp. bulgaricus B14. Int Dairy J 1994;4:409-27.

[18] Magboul AAA, McSweeney PLH. Purification and characterization of an aminopeptidase from Lactobacillus curvatus DPC2024. Int Dairy J 1999;9:107-16.

[19] Eggimann B, Bachmann M. Purification and partial characterization of an aminopeptidase from Lactobacillus lactis. Appl Environ Microbiol 1980;40:876-82. 